\title{
Growth ring analysis of Euxylophora paraensis through x-ray microdensitometry
}

\author{
Eva Santos de Andrade ${ }^{1}$ Silvana dos Santos Carvalho Garcia ${ }^{2}$ \\ Ana Luisa Kerti Mangabeira Albernaz ${ }^{3}$ Mario Tomazello Fillho ${ }^{4}$ \\ Victor Hugo Pereira Moutinho
}

'Engenharia Florestal, Universidade Federal do Oeste do Pará (UFOPA), Santarém, PA, Brasil.

${ }^{2}$ Museu Paraense Emílio Goeldi, Av. Perimetral, 1901, Terra Firme, 66077-830, Belém, PA, Brasil. E-mail: silvanasancarcia@gmail.com. Corresponding author.

${ }^{3}$ Programa de Pós-graduação em Biologia Tropical - MPEG, Belém, PA, Brasil.

${ }^{4}$ Departamento de Ciências Florestais da Escola Superior de Agricultura "Luiz de Queiroz", Universidade de São Paulo (USP), Piracicaba, SP, Brasil. ${ }^{5}$ Laboratório de Tecnologia da Madeira, Universidade Federal do Oeste do Pará (UFOPA), Santarém, PA, Brasil.

ABSTRACT: Euxylophora paraensis Huber - Rutaceae, popularly known as yellow heart, is a species with a low-density population that has suffered intense exploitation in recent decades. This has led to its inclusion in the IBAMA list of endangered species. This study aimed to evaluate the existence of growth rings and their annuity in five trees of Euxylophora paraensis through the x-ray microdensitometry technique, as well as to compare them using the classical method. Application feasibility of this technique can be deepened through future, broader dendroecological studies, which may better elucidate the understanding of the species population dynamics and promote more sustainable uses. Wood disks were collected from the base of five 29-year-old trees from a planting site in the Curua-Una Experimental Station, located in Prainha, Pará State, Brazil. Samples were polished and sanded for the $x$-ray microdensitometric analysis. Values of minimum, average, and maximum density $(0.581,0.84$, and $1.077 \mathrm{gcm}^{-3}$, respectively) were obtained. There was a significant difference in density between the studied trees. Growth rings boundaries, through densitometric pith-bark profile are demarcated by fibrous zones, with density variation between the early wood and late wood. This study concludes that the growth rings of the studied species are distinct and annual, validating the technique used.

Key words: dendrochronology, yellow heart, density, Amazon.

Análise dos anéis de crescimento de Euxylophora paraensis por meio da microdensitometria de raios-x

RESUMO: Euxylophora paraensis Huber - Rutaceae, popularmente conhecida como pau amarelo, é uma espécie com baixa densidade populacional e que sofreu intensa exploração nas últimas décadas. Isso levou à sua inclusão na lista do IBAMA de espécies ameaçadas de extinção. O presente estudo objetiva avaliar a existência e anuidade dos anéis de crescimento de cinco árvores de Euxylophora paraensis, por meio da técnica de microdensitometria de Raio-x, e comparar com o uso do método clássico. A viabilidade da aplicação dessa técnica poderá ser aprofundada por meio de futuros estudos dendroecológicos mais amplos, que poderão melhor elucidar a compreensão da dinâmica populacional da espécie e promover usos mais sustentáveis. Coletou-se discos do lenho da base de cinco árvores, provenientes de plantio, na Estação experimental de Curua-Una, em Prainha-PA, com então 29 anos de idade. As amostras foram plainadas e polidas, visando a análise microdensitometrica de raios $x$. Foram obtidos valores de densidade mínimos, médios e máximos (respectivamente 0,581, 0,84 e 1,077gcm-3). Houve diferença significativa na densidade entre as árvores estudadas. Verificou-se, por meio do perfil densitométrico no sentido medulacasca, limites dos anéis de crescimento por zonas fibrosas, com variação da densidade entre o lenho inicial e tardio. Verifica-se que os anéis de crescimento da espécie estudada são distintos e anuais, validando a técnica utilizada.

Palavras-chave: dendrocronologia, pau amarelo, densidade, Amazônia.

\section{INTRODUCTION}

Use of wood resources in the Eastern Amazon is intense and normally performed in a non-sustainable way, which may lead to irreversible damages to the remaining forest, raising fire risk, and threatening the population of high commercial-value species (NEPSTAD et al., 1999; PINTO et al., 2002; FRANCEZ et al., 2007; ALMEIDA et al., 2013). This is due to unplanned forest harvest, performed in an intensive and selective way, which turns forests with high wood stocks and commercial value into degraded forests with low commercial value and difficulty restoring biodiversity (PINTO et al., 2002). 
Species that have a low natural population density but high commercial value are those most affected by population reduction, causing them to begin the extinction process. An example is Euxylophora paraensis Huber. Currently, this species is on national lists of endangered species, such as the list from the Instituto Brasileiro do Meio Ambiente (IBAMA) (IBAMA, 2014) and the list from the state of Pará (SEMA, 2009). Euxylophora paraensis Huber, which is from the Rutaceae Juss. family, is popularly known as yellow heart. In addition, this species is monotypic, belonging to the Euxylophora genus, which only includes the Euxylophora paraensis Huber species (PIRANI, 2016). Its occurrence is limited to northern Brazil (ISIDORO et al., 2012), and it has high silvicultural and economic value and low population density (MESSINA, 2016).

According to ALVES et al. (2012) and WHEELER (2011), Euxylophora does not have distinct growth rings; however, LOUREIRO \& DA SILVA (1968) and GARCIA (2014) claim the existence of slightly distinct and distinct growth rings, respectively. Associated with this information, BOTOSSO \& TOMAZELLO FILHO (2001), WORBES (2002), and LISI et al. (2008) asserted that growth rings can be distinguished in diverse species of the Rutaceae family, to which Euxylophora belongs.

A growth ring is not necessarily evidence of an annual formation. WIMMER et al. (2000) and HIENRICH (2004) ascribe the formation of diverse false rings in the Amazon region to the lack of a welldefined seasonal climate, compared to temperate regions. However, annual growth rings have been reported in flooded forests of Amazon, where the elevation of the river level causes stress that leads to differential growth (SCHONGART et al., 2002). More recently, a study on the Belterra-Pa region indicated the marking of growth rings in 26 of 64 analyzed species (TREVIZOR et al., 2015). This region belongs to an area called the 'dry corridor' of the Amazon due to its well-defined dry season (BUSH, 1994).

$\mathrm{X}$-ray microdensitometry is a growth ring analysis technique that was developed in the 1960s by Pouge in France (POLGE, 1965), and it was used for the first time in Brazil by AMARAL \& TOMAZELLO FILHO (1998). Through this technique, it is possible to verify millimeter by millimeter the differences of wood densities, enabling the identification of early wood and latewood and the check of their densities. According to TOMAZELLO FILHO et al. (2008), this allows the delimitation of growth rings through the detailed building of the apparent density profile of the wood. In this way, accurate information can be obtained about the periodicity of the wood formation and the age that tropical trees reach (BOTOSSO \& MATTOS, 2002). For this reason, $\mathrm{x}$-ray microdensitometry is considered a complementary technique of the classic dendrochronology.

This research aimed to evaluate the viability of studying Euxylophora paraensis growth through the study of growth rings. Since the species is endangered and it is not possible to have several samples, we decided to use the x-ray microdensitometry technique in samples of Euxylophora paraensis, in which the age is known, in a well-defined seasonality region. The hypothesis is that the species marks annual growth rings that can be analyzed through the x-ray microdensitometry technique. It is expected to contribute to the development of tools that promote management of the species compatible with the conservation of its populations.

\section{MATERIALS AND METHODS}

Sampling

Five 29-year-old Euxylophora paraensis Huber trees were selected. The trees are part of an experimental planting that started in 1982 in the experimental station of Curua-Una, which is located in the Barreirinha Community, city of Prainha-PA, between the coordinates $\mathrm{S} 02^{\circ} 32^{\prime} 40,1^{\prime \prime}$ and $\mathrm{W} 054^{\circ} 05^{\prime} 26,9^{\prime \prime}$, which is also located in the so-called 'dry corridor' of the Amazon. Seeds used in the experiment were collected in the primary forests in the region.

The selection of trees was made considering individuals without defects and visible defilements, straight stem, high circumference at breast height $(\mathrm{CBH})$ and conditions of safe fall, in order to avoid impact to adjacent trees. Wood samples were taken as disks from the trunk base in September 2012, when botanic material was also collected for identification by a specialist of the herbarium of the Museu Paraense Emílio Goeldi.

\section{Material analysis}

In the laboratory, disks were naturally dried, and then they were planed and sanded with the variation of granulometry between 60 and 400 mesh, aiming to improve the visualization of growth rings. Then, the central region was removed from each disk, with dimensions of $2 \times 1.5 \mathrm{~cm}$ of width and thickness, respectively, with variable length, according to the diameter of the selected material. 
Wood samples were glued in wood supports, and their transversal sections were cut at 2 millimetres of thickness with parallel circular double blade equipment, resulting in a sample with 2 millimetres of thickness and 5 millimetres of width. Then, those samples were stocked in a climate-controlled room at $20^{\circ} \mathrm{C}$ and $65 \%$ relative air humidity for 24 hours to reach the wood equilibrium humidity of $12 \%$ (AMARAL \&TOMAZELLO FILHO, 1998).

\section{$X$ ray microdensitometry}

The apparent density profile of the wood was obtained with the QTRS-01X equipment of Quintek Measurement Systems in the radial direction of the samples (pith-bark direction) in each 0.04 millimetres, according to the recommendation of CHAGAS (2013). Later, the mean values of density were obtained for each tree, which were submitted to the Scott-Knott test of mean differentiation at the probability level of 5\%.

At the same time of the x-ray densitometry, the growth rings were measured by the traditional methodology. For this measurement, four rays from each disk were analysed under a Leica stereoscope, MZ10 model, which has an optical fiber illumination system. Then, the analyzed rays were scanned by an HP Scan jet G2710 scanner with 1200dpi of resolution with a scale for later measurement of the growth rings' width using the Image Pro Plus software. The obtained data were developed in the COFECHA software, aiming to control quality and synchronization between trees. Finally, the densitometry data were compared due to the higher attenuation of growth rings relative to latewood.

\section{RESULTS AND DISCUSSION}

The mean, minimum, and maximum values of apparent density at $12 \%$ wood humidity of yellow heart trees were $0.84,0.581$, and $1.077 \mathrm{gcm}^{-3}$, respectively. The standard deviation was 0.076 , and the variation coefficient was $9.077 \%$ (Table 1 ).

There was a significant difference between mean densities; whereas, samples of only two trees had a statistically equal mean. The difference between average values of density generally occurs due to the wood formation and composition of the anatomic structure of the tree. CASTRO et al. (2014) explain that the trees with a higher mean value of apparent density present a higher percentage of latewood, resulting in an increase of density due to the higher attenuation of $\mathrm{x}$-rays, whereas trees with a lower apparent density of wood present a higher percentage of early wood, decreasing the mean value density. Even though the studied trees had the same silvicultural treatment, were of the same age, were grown under the same edaphic and climate conditions, and had their seeds collected from the same primary forest, the different genetic materials seem to be the more plausible explanation for the variation between individuals.

Considering that density profiles are related to the anatomic structure of growth rings, it is suggested that the average of the maximum values of $1.077 \mathrm{gcm}^{-3}$ for apparent density is related to latewood; whereas, the average of minimum values of $0.581 \mathrm{gcm}^{-3}$ is related to early wood. According to BOTOSSO \& MATTOS (2002), this fact occurs due to the match of early wood to the vegetative period with a higher physiological activity, when the cell walls are less thick and have low density. However,

Table 1 - Mean values obtained from apparent density readings of the samples of five Euxylophora paraensis trees from the planting of Curuá-Una Experimental Station. SD: standard deviation; CV: coefficient of variation; Max: maximum value; Min: minimum value.

\begin{tabular}{|c|c|c|c|c|c|}
\hline \multirow{2}{*}{ Tree } & \multirow[b]{2}{*}{ Mean } & \multirow[b]{2}{*}{ SD } & \multirow[b]{2}{*}{ CV (\%) } & \multirow[b]{2}{*}{$\operatorname{Max}$} & \multirow[b]{2}{*}{ Min } \\
\hline & & & & & \\
\hline 1 & $0.819 \mathrm{a}$ & 0.072 & 8.760 & 1.080 & 0.579 \\
\hline 2 & $0.889 \mathrm{~d}$ & 0.073 & 8.186 & 1.118 & 0.666 \\
\hline 3 & $0.823 \mathrm{~b}$ & 0.087 & 10.607 & 1.082 & 0.524 \\
\hline 4 & $0.836 \mathrm{~b}$ & 0.072 & 8.562 & 1.057 & 0.575 \\
\hline 5 & $0.833 \mathrm{c}$ & 0.077 & 9.273 & 1.051 & 0.563 \\
\hline Mean & 0.840 & 0.076 & 9.077 & 1.077 & 0.581 \\
\hline
\end{tabular}

Means followed by the same letter in the column do not show statistically significant differences according to the Scott-Knott test at $5 \%$ significance. 
the latewood corresponds to the end of the vegetative period, when the cell walls gradually become thicker and; consequently, have higher density. Higher density reflects the darker tone than the early wood. This is clearly emphasized in the wood transversal section (Figure 1), as verified by CASTRO et al. (2014), who studied the x-ray micro densitometry in Pinus caribaea var. hondurensis (Pinaceae).

The diametric apparent density profiles of the sampled trees showed an increasing density value in the radial direction and a value decrease in the sapwood region. This variation model was also observed by ALVARADO et al. (2010) for Swietenia macrophylla species, which presented higher density values due to a higher percentage of adult wood and the deposition of extractives in the heartwood region; in the sapwood, the functional region of the xylem, a reduction of the apparent density of wood compared to heartwood was reported.

Some samples presented stain fungi in the sapwood region, making the visualization of growth rings through the traditional methodology difficult. However, through the densitometry profile, it was possible to clearly visualize and associate the right localization of limits of growth rings in density peaks. According to TOMAZELLO FILHO et al. (2008), the action of those xilophagous organisms can occasion the decrease in density values, including the minimum, medium, and maximum values. Moreover, the density decrease in the regions affected by fungus induced the decrease in resistance (BRAZOLIN et al., 2011).

It was verified through the profiles that density peaks are more attenuated in the limits of growth rings, where it is possible to visualize fibrous zones with dark coloring, interleaved by the lighter coloring. According to TOMAZELLO FILHO et al. (2001), this occurs as a response of the cambial activity to the seasonality of environmental conditions (temperature, precipitation, luminosity, etc.), which reflects in the anatomy and other wood properties. In the studied case, even the environmental variables were not measured, and it is believed that the main influence was the precipitation, since the studied region has a well-defined dry season; however, the region does not have a high annual variation of temperature and luminosity.

The counting and measurement of growth rings by the traditional methodology returned the age of 29 years for the studied trees, with a correlation of 0.595 between them and a significance level of 0.515 , corroborating with the planting age. All studied trees presented the last growth ring as incomplete. In this regard, it is important to note that the sampling occurred in September, id est, before the rainy season had started, preventing the tree from completing the last growth ring. Thus, that ring cannot be measured and counted as the others.

Through the densitometry, it was possible to verify the same quantity of growth rings, beyond the false rings, which are also reported in the traditional methodology. The presence of false rings in Amazon species was also observed by ALVARADO et al. (2010), who emphasized the importance of identifying the presence of intra-annual growth rings in growth studies based on dendrochronology techniques. Both the densitometry and the traditional method required quality control to differentiate false rings from

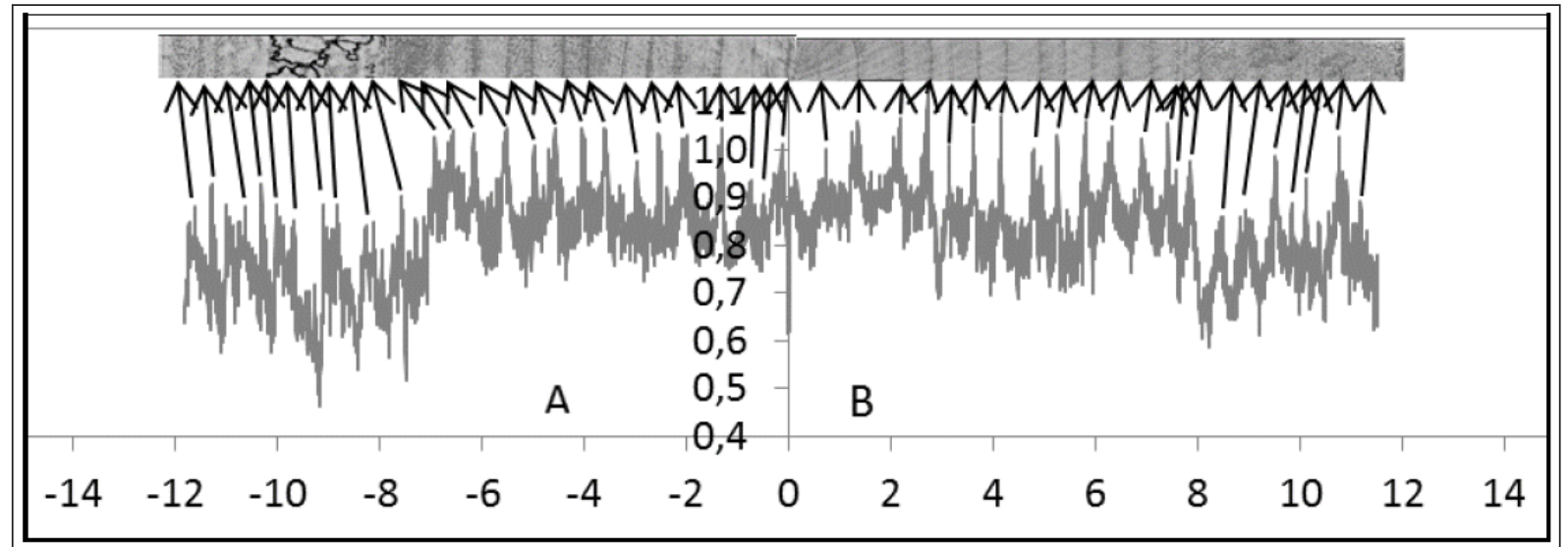

Figure 1 - Radial density profile of a Euxylophora paraensis sample, with the density peaks associated with the darker regions, corresponding to latewood. On the left is the fungi presence as well as lower readings of wood density for that region. 
annual rings. Furthermore, by the densitometry, it was possible to define limits of growth rings by the density variation, demonstrating the efficiency of that technique as a methodology.

\section{CONCLUSION}

The growth rings of the Euxylophora paraensis Huber species are distinct and annual. The $\mathrm{x}$-ray microdensitometry was efficient in the delimitation of growth ring boundaries of the $\boldsymbol{E}$. paraensis. It is possible to associate the density peaks obtained by the densitometry with the age of the planting obtained by the traditional methodology of dendrochronology. The simultaneous use of two methods enabled a better count calibration, decreasing the error margin of the age estimate, which can be caused, for example, by the existence of false rings.

\section{REFERENCES}

ALMEIDA, L.S.et al. Use of plant species in the rural community of Santo Antônio, BR 163 highway, Brazilian amazon. Floresta e Ambiente, Seropédica, v.20, n.4, p.435-446, 2013. Available from: $<\mathrm{http} / / / \mathrm{dx}$.doi.org/10.4322/floram.2013.044>. Accessed: Dec. 19, 2016. doi: 10.4322/floram.2013.044.

ALVARADO, J.R. et al. Variation of wood density and relationship with the tree-ring width of mahogany trees, Swietenia macrophylla, from Amazonian tropical forest of Peru. Scientia Forestalis, Piracicaba, v.38, n.86, p.171-179, 2010. Available from: <http://www.ipef.br/publicacoes/scientia/nr86/cap05.pdf> Accessed: Dec. 19, 2016.

ALVES, R.C. et al. Caracterização anatômica macroscópica de madeiras folhosas comercializadas no Estado do Espírito Santo. Floresta e Ambiente, Seropédica, v.19, n.3,p.352-361, 2012. Available from: <http://dx.doi.org/10.4322/floram.2012.042> Accessed: Dec. 19, 2016. doi: 10.4322/floram.2012.042.

AMARAL, A. C. B.; TOMAZELLO FILHO, M. Avaliação das características dos anéis de crescimento de Pinus taeda pela microdensitometria de raios X. Revista Ciência e Tecnologia, Piracicaba, v.6, n.11, p.17-23, 1998 .

BOTOSSO, P. C.; MATTOS, P. P. Conhecer a idade das árvores: importância e aplicação. Colombo: Embrapa Florestas, Revista Embrapa, Colombo, PR, 2002. 25p.

BOTOSSO, P. C.; TOMAZELLO FILHO, M. Aplicação de faixas dendrométricas na dendrocronologia: avaliação da taxa e do ritmo de crescimento do tronco de árvores tropicais e subtropicais. In: MAIA, N.B.et al. (Org.). Indicadores ambientais: conceitos e aplicações. São Paulo: EDUC, 2001. p.145-171.

BRAZOLIN, S. et al. Wood evaluation of deteriorated wood of tipuana trees (Tipuana tipu) in urban areas: macroscopic analysis and specific gravity. Scientia Forestalis, Piracicaba, v.39, n.91, p.291-299, 2011. Available from: <http://www.ipef.br/publicacoes/ scientia/nr91/cap01.pdf>. Accessed: Dec. 19, 2016.
BUSH, M. B. Amazonian speciation: a necessarily complex model. Journal Biogeography, Oxford, v.21, n.1, p.5-17, 1994. Available from: <https://www.jstor.org/stable/2845600>. Accessed: Dec. 19, 2016. doi: $10.2307 / 2845600$.

CASTRO, V. R. et al. Evaluation radial profile of the wood of Pine trees (Pinus caribaea var. hondurensis Barr. Et. Golf.) by X-ray densitometry. ScientiaForestalis, Piracicaba, v.42, n.103, p.353360, 2014. Available from: <http://www.ipef.br/publicacoes/ scientia/nr103/cap05.pdf>. Accessed: Dec. 19, 2016

CHAGAS, M. P. Anéis de crescimento do lenho de árvores como monitores ambientais: avaliação temporal e espacial da poluição atmosférica na cidade de Paulínia, São Paulo. 2013. 159f. Tese (Doutorado em Recursos Florestais) - Universidade de São Paulo, Piracicaba, São Paulo, SP

FRANCEZ, L. M. B. et al. Changes on floristic composition after logging in a terra firme forest in the region of Paragominas, PA. Acta Amazonica, Manaus, v.37, n.2, p. 219228, 2007. Available from: <http://www.scielo.br/pdf/aa/v37n2/ v37n2a07>. Accessed: Dec. 19, 2016.

GARCIA, S. S. C. Estudos dendrocronológicos em Euxylophora paraensis Huber (Rutaceae) e Carapa guianensis Aubl. (Meliaceae) provenientes de plantios em terra firme na Amazônia Oriental. 2014. 60f. Dissertação (Mestrado em botânica tropical) - Universidade Federal Rural da Amazônia e Museu Emílio Goeldi, Belém, PA.

HIENRICH, I. Dendroclimatology of Toona ciliate. 2004. 235 f. Thesis ( $\mathrm{PhD}$ in management resources and environmental science) - School of Resources, Environment and Society, Australian National University, Ganberra.

IBAMA. Lista de espécies ameaçadas de extinção. 2014. Available from: <http://www.ibama.gov.br/documentos/lista-deespecies-ameacadas-de-extincao>. Accessed: May 03, 2015.

ISIDORO, M. M. et al. Phytochemical and chemosystematic studies of Euxylophora paraensis (Rutaceae). Quimica Nova, São Paulo, v.35, n.11, p.2119-2124, 2012. Available from: <http://dx.doi.org/10.1590/ S0100-40422012001100004>. Accessed: Dec. 19, 2016.

LISI, C. S. et al. Tree-ring formation, radial incremente periodicity and phenology of tree species from a seasonal semi-deciduous forest in southeast Brazil. IAWA Journal, Utrecht, v.29, p.189207, 2008. Available from: <http://www.iawa-website.org/search. html volume $=29 \&$ issue $=2>$. Accessed: Dec. 19, 2016. doi: $10.1163 / 22941932-90000179$

LOUREIRO, A. A.; DA SILVA, M. F. Catálogo de madeiras da Amazônia - Segundo Volume. Belém: SUDAM, 1968. 408p.

MESSINA, T. Euxylophora paraensis Huber, Avaliação de risco de extinção. Available from: < http://cncflora.jbrj.gov.br/portal/ptbr/profile/Euxylophora\%20paraensis>. Accessed: Nov. 09, 2016.

NEPSTAD, D. C. et al. Large-scale impoverishment of Amazonian forests by logging and fire. Nature, Hampshire, v.398, p.505-508, 1999. Available from: <http://www.nature. com/nature/journal/v398/n6727/full/398505a0.html>. Accessed: Dec. 9. 2016. doi: 10.1038/19066.

PINTO, A. C. M. et al. Analysis of logging damage in a moist tropical forest under sustained management in western amazon. 
Revista Arvore, Viçosa, v.26, n.4, p.459-466, 2002. Available from: <http://www.scielo.br/pdf/rarv/v26n4/a08v26n4.pdf>. Accessed: Dec. 19. 2016.

PIRANI, J. R. Euxylophora. Lista de Espécies da Flora do Brasil. Jardim Botânico do Rio de Janeiro. Online. Available from: $<$ http:// floradobrasil.jbrj.gov.br/jabot/floradobrasil/FB621>. Accessed: Jan. 14, 2016.

POLGE, H. Study of wood density variations by densitometric analysis of X-ray negatives of samples taken with a Pressler Auger. In: SYMPOSIUM OF I.U.F.R.O., SECTION 41, Melbourne. Proceedings... Melbourne: IUFRO, 1965. 19p.

SECRETARIA DE MEIO AMBIENTE E SUSTENTABILIDADE (SEMA). Lista de espécies da flora e da fauna ameaçadas no Estado do Pará. Online. Available from: <http://www.sema. pa.gov.br/2009/03/27/9439/>. Accessed: Feb. 06, 2015.

SCHONGART, J. et al. Phenology and stem-growth periodicity of tree species in Amazonian floodplain forests. Journal of Tropical Ecology, Cambridge, v.18, n.2, p.581-597, Mar. 2002. Available from: <http://www.uni-goettingen.de/en/108425.html>. Accessed: Dec. 19. 2016. doi: 10.1017/S0266467402002389.

TOMAZELLO FILHO, M. et al. Análise e aplicação dos anéis de crescimento das árvores como indicadores ambientais: dendrocronologia e dendroclimatologia. In: MAIA, N.B.et al. (Eds.). Indicadores ambientais: conceitos e aplicações. São Paulo: EDUC, 2001. p.117-143.
TOMAZELLO FILHO, M. et al. Application of x-ray technique in non destructive evaluation of eucalyptus wood. Maderas: Ciencia y Tecnologia, Concepcion, v.10, n.2, p.139-150, 2008. Available from: <http://dx.doi.org/10.4067/S0718221X2008000200006>. Accessed: Dec. 19. 2016. doi: 10.4067/ S0718-221X2008000200006.

TREVIZOR, T. T. et al. Caracterização do lenho e potencial da dendrocronologia aplicada às espécies tropicais. In: ALBERNAZ, A.L.(Org). Distrito florestal sustentável da BR-163: dinâmicas sociais, mudanças ambientais e produção florestal. Belém: MPEG, 2015. p.291-308.

WHEELER, E.A. InsideWood: a web resource for hardwood anatomy. IAWA Journal, Leiden, v.32, n.2,p.199-211, 2011. Available from: $<$ http:/www.iawa-website.org/search.html? volume=32\&issue=2>. Accessed: Dec. 19. 2016. doi: 10.1163/22941932-90000051.

WIMMER, R. et al. Use of false rings in Austrian pine to reconstruct early growing season precipitation. Canadian Journal Forest Research, Ottawa, v.30, p.1691-1697, 2000. Available from: <http://www.nrcresearchpress.com/doi/ pdf/10.1139/x00-095>. Accessed: Dec. 19, 2016. doi: 10.1139/ cjfr-30-11-1691.

WORBES, M. One hundred years of tree-ring research in the tropics: a brief history and an outlook to future challenges. Dendrochronologia, Munich ,v.20, n.1-2,p.217-231, 2002. Available from: <http://dx.doi.org/10.1078/1125-7865-00018>. Accessed: Dec. 19, 2016. 